Jurnal IImiah : Biologi Eksperimen dan Keanekaragaman Hayati

Vol. 2 No. 1 Mei 2014 : hal. 1-5

ISSN : 2338-4344

\title{
EFEK EKSTRAK LADA HITAM (Piper nigrum L.) TERHADAP LIBIDO MENCIT (Mus musculus L.) JANTAN YANG BERBEDA UMUR
}

\section{EFFECT OF BLACK PEPPER (Piper nigrum L.) EXTRACT ON MALE MICE (Mus musculus L.) LIBIDO OF DIFFERENT AGE}

\author{
Tia Wida Ekaputri $\mathrm{Hz}^{1}$, M. Kanedi ${ }^{1}$, Sutyarso ${ }^{1}$, Hendri Busman ${ }^{1}$ \\ 1 Jurusan Biologi FMIPA, Universitas Lampung, Bandar Lampung, Indonesia \\ Email: tia_outstanding@ymail.com \\ Jurusan Biologi FMIPA Universitas Lampung \\ Jl. Soemantri Brojonegoro No.1, Bandar Lampung, Lampung, Indonesia, 35145
}

\begin{abstract}
Abstrak
Adanya efek merugikan dari pengobatan modern untuk masalah fungsi seksual, maka masyarakat lebih memilih pengobatan tradisional dengan menggunakan tanaman yang berkhasiat afrodisiak. Tujuan dari penelitian ini adalah untuk mengetahui efek ekstrak lada hitam (Piper nigrum L.) terhadap libido mencit (Mus musculus L.) jantan yang berbeda umur. Tiga puluh dua ekor mencit jantan dibagi menjadi 2 kelompok umur, yaitu kelompok muda berumur 4 bulan (K1) dan kelompok tua berumur 6 bulan (K2). Masing-masing kelompok muda dan tua terdiri dari 5 individu. Masing-masing kelompok diberi perlakuan, yaitu kontrol (P0), pakan dengan ekstrak air lada hitam (P1), pakan dengan ekstrak etanol lada hitam (P2), pakan dengan ekstrak air dan etanol lada hitam (P3) selama 3 bulan. Perilaku seksual diamati pada akhir waktu pemberian perlakuan. Parameter yang diukur adalah latensi percumbuan, latensi penunggangan, dan frekuensi penunggangan. Data dianalisis menggunakan ANARA dua jalur, kemudian dilanjutkan dengan uji BNT dengan a 0,05. Hasil analisis menunjukan bahwa latensi percumbuan dari perlakuan P2 dan P3 pada kelompok umur tua berbeda nyata dibandingkan dengan kontrol $(p=0,013, p=0,046)$. Latensi penunggangan dan frekuensi penunggangan dari perlakuan P2 pada kelompok muda berbeda nyata dibandingkan dengan kontrol $(p=0,026, p=0,010)$ dan dengan kelompok tua $(p=0,024, p=0,022)$. Simpulan penelitian ini adalah ekstrak lada hitam dapat meningkatkan libido mencit jantan.
\end{abstract}

Kata kunci: lada hitam (Piper nigrum L.), afrodisiak, libido, mencit (Mus musculus L.) jantan

\begin{abstract}
There is adverse effect of modern treatment for sexual disfunction, so people prefer traditional treatment by using herb with aphrodisiac effect. The purpose of this research is to analyze the effect of black pepper (Piper nigrum L.) extract on male mice (Mus musculus L.) libido of different age. Thirty two male mice were divided into 2 age groups, the younger group aged 4 months (K1) and the older group aged 6 months (K2). Each group both younger and older was consisted of 5 mice. Each group was given by four treatment, control (P0), feeding with black pepper aquous extract (P1), feeding with black pepper ethanolic extract (P2), and feeding with black pepper aquous and ethanolic extract (P3) for 3 months. Sexual behavior was observed at the end of treatment period. The parameter measured was introducing latency, mounting latency, and mounting frequency. The data were analyzed by using two ways ANOVA followed by LSD test with a 0,05 . The results show that introducing latency of treatment P2 and P3 in older group differ significantly compared to control $(p=0,013, p=0,046)$. Mounting latency and mounting frequency of treatment $P 2$ in younger group differ significantly compared to control $(p=0,026, p=0,010)$ and to older group $(p=0,024, p=0,022)$. Therefore it is concluded that black pepper extract enhances libido of male mice.
\end{abstract}

Keywords: black pepper (Piper nigrum L.), aphrodisiac, libido, males mice (Mus musculus L.)

\section{PENDAHULUAN}

Gangguan libido banyak dialami oleh pria berusia lanjut yang diakibatkan oleh penurunan fungsi fisiologis organ tubuh dibandingkan dengan pria berusia produktif. Gangguan gairah seksual ini merupakan masalah penting dalam kehidupan seseorang, sehingga banyak inovasi yang dilakukan untuk mengatasinya. Pengobatan tradisional dengan menggunakan tanaman yang berkhasiat afrodisiak banyak dipilih masyarakat karena memiliki efek samping yang tidak berbahaya dibandingkan dengan pengobatan modern (Syamsul, 2011). 
Majeed dan Prakash (2000) menyatakan bahwa salah satu jenis tanaman rempah yang telah lama digunakan sebagai ramuan obat tradisional dalam sistem pengobatan India kuno Ayurveda adalah lada hitam (Piper nigrum L.). Lada hitam mengandung zat pedas, yaitu piperin yang berfungsi sebagai afrodisiak (Darling, 2002). Lada hitam juga mengandung amida fenolat, asam fenolat, dan flavonoid yang berfungsi sebagai antioksidan (Meghwal dan Goswami, 2012).

Piperin telah dilaporkan dapat meningkatkan kadar gonadotropin dalam serum dengan cara menghambat feedback negatif ke hipofisis pada tikus jantan (D'Cruz dan Mathur, 2005). Gonadotropin yang dihasilkan hipofisis, terutama LH akan merangsang testis, dalam hal ini sel Leydig, untuk menghasilkan testosteron (Molina, 2004). Telah diketahui bahwa ada korelasi antara libido dengan testosteron, maka sangat diharapkan bahwa kadar testosteron yang tinggi dapat memperbaiki dorongan seks yang rendah (Nalbandov, 1990).

\section{BAHAN DAN METODE}

\section{Persiapan Hewan Uji}

Mencit jantan dan betina diperoleh dari Balai Penyidikan dan Pengujian Veteriner (BPPV) Regional III Bandar Lampung. Sebelum penelitian dimulai, terlebih dahulu dipersiapkan tempat pemeliharaan hewan uji, yaitu kandang berupa bak plastik segi empat ukuran $30-37 \mathrm{~cm}$, tutup kandang dari kawat screen yang berfungsi juga sebagai tempat pemberian pakan, serbuk kayu sebagai alas kandang, dan tempat minum mencit dari botol plastik yang disumbat pipa alumunium.

\section{Pembuatan Ekstrak Lada Hitam (Piper nigrum L.)}

Ekstrak air lada hitam dibuat dengan cara mencampurkan $50 \mathrm{~g}$ serbuk lada hitam dan 500 $\mathrm{ml}$ aquades yang telah mendidih dan telah diangkat dari pemanas. Kemudian dilanjutkan dengan proses pengadukan, penyaringan, dan penguapan sampai diperoleh ekstrak air lada hitam dalam bentuk pasta.

Ekstrak etanol lada hitam dibuat dengan cara mencampurkan $50 \mathrm{~g}$ serbuk lada hitam dan sepertiga dari $500 \mathrm{ml}$ etanol $95 \%$. Kemudian dilanjutkan dengan proses maserasi dengan menggunakan shaker sebanyak 3 kali. Maserat diambil untuk proses penyaringan dan penguapan sampai diperoleh ekstrak etanol lada hitam dalam bentuk pasta.
Estrak air dan etanol lada hitam dibuat dengan cara mencampurkan ekstrak air dan ekstrak etanol de-ngan perbandingan berat yang sama.

\section{Rancangan Percobaan}

Mencit jantan dibagi menjadi 2 kelompok umur, yaitu kelompok muda berumur 4 bulan (K1) dan kelompok tua berumur 6 bulan (K2). Perlakuan terdiri dari pakan murni sebagai kontrol (P0), pakan yang diberi ekstrak air (P1), pakan yang diberi ekstrak etanol (P2), dan pakan yang diberi ekstrak air dan ekstrak etanol (P3).

\section{Cara Pemberian Ekstrak Lada Hitam}

Ekstrak lada hitam diberikan kepada mencit jantan melalui pakan. Pembuatan pakan dilakukan dengan cara menambahkan ekstrak lada hitam sebanyak $0,3 \mathrm{~g}$ pada setiap $1 \mathrm{~kg}$ pakan mencit. Ekstrak dicampur secara merata dengan pakan kemudian dicetak u-lang untuk memperoleh pelet dalam bentuk batangan. Pemberian ekstrak lada hitam dilakukan selama 3 bulan.

\section{Cara Pengujian Libido}

Pengujian libido dilakukan dengan cara uji kawin pada akhir waktu pemberian perlakuan. Mencit jantan yang telah diberi perlakuan bersama mencit betina yang sedang estrus dimasukkan ke dalam bak uji dan keduanya dipisahkan oleh sekat triplek. Setelah 5 menit, sekat pemisah dilepas dan direkam aktivitas seksual yang terjadi dengan menggunakan kamera digital dan stopwatch selama 10 menit.

\section{Data dan Analisis Data}

Data parameter libido diperoleh dengan cara melihat hasil rekaman aktivitas seksual yang meliputi:

Latensi percumbuan, yaitu waktu sejak mencit jantan dan mencit betina dipertemu-kan (sekat dibuka) hingga terjadi percum-buan pertama.

Latensi penunggangan, yaitu waktu sejak mencit jantan dan mencit betina dipertemu-kan (sekat dibuka) hingga terjadi penung-gangan pertama.

Frekuensi penunggangan, yaitu banyaknya penunggangan yang dilakukan mencit jan-tan selama waktu 10 menit.

Data dianalisis dengan menggunakan two ways Analysis of Variance (ANOVA) untuk mengetahui ada tidaknya perbedaan antar perlakuan dan umur. Apabila terdapat perbedaan yang nyata maka dilan-jutkan dengan uji beda nyata terkecil (BNT) pada taraf $5 \%$. 


\section{HASIL DAN PEMBAHASAN}

\section{Latensi Percumbuan}

Tabel 1. Rata-rata latensi percumbuan mencit jantan (detik) antara kelompok umur muda dan tua

\begin{tabular}{ccc}
\hline \multirow{2}{*}{ Perlakuan } & \multicolumn{2}{c}{ Latensi Percumbuan \pm SD (detik) } \\
\cline { 2 - 3 } & K1 & K2 \\
\hline P0 & $19.25 \pm 26.59$ & $31.00 \pm 5.77$ \\
\hline P1 & $11.50 \pm 5.74$ & $7.00 \pm 6.63$ \\
\hline P2 & $12.75 \pm 8.77$ & $12.25 \pm 9.21$ \\
\hline P3 & $5.00 \pm 1.63$ & $22.75 \pm 16.99$ \\
\hline
\end{tabular}

Tanda * pada tabel menunjukan perbedaan yang nyata

Hasil analisis statistik menunjukan bahwa ratarata latensi percumbuan mencit jantan PO kelompok muda dengan kelompok tua tidak berbeda nyata. Rata-rata latensi percumbuan mencit jantan P1, P2, P3 kelompok muda dengan kelompok tua tidak berbeda nyata. Dengan demikian, kemampuan mencit jantan kelompok tua dalam melakukan percumbuan menyamai mencit jantan kelompok muda. Hal tersebut kemungkinan dapat terjadi karena kedua kelompok umur mencit jantan hanya berbeda dua bulan, sehingga belum bisa menunjukan perbedaan tanda-tanda penuaan yang signifikan.

Tabel 2. Rata-rata latensi percumbuan mencit jantan (detik) antara perlakuan kontrol dengan per-lakuan ekstrak lada hitam

\begin{tabular}{|c|c|c|c|}
\hline \multirow[b]{2}{*}{ Umur } & \multirow[b]{2}{*}{ Perlakuan } & \multicolumn{2}{|c|}{ Latensi Percumbuan \pm SD (detik) } \\
\hline & & $\begin{array}{c}\text { Diberi ekstrak } \\
\text { lada hitam }\end{array}$ & Kontrol (P0) \\
\hline \multirow{3}{*}{$\mathrm{K} 1$} & P1 & $11.50 \pm 5.74$ & $19.25 \pm 26.59$ \\
\hline & $\mathrm{P} 2$ & $12.75 \pm 8.77$ & $19.25 \pm 26.59$ \\
\hline & P3 & $5.00 \pm 1.63$ & $19.25 \pm 26.59$ \\
\hline \multirow{3}{*}{$\mathrm{K} 2$} & P1 & $7.00 \pm 6.63^{*}$ & $31.00 \pm 5.77^{*}$ \\
\hline & $\mathrm{P} 2$ & $12.25 \pm 9.21^{*}$ & $31.00 \pm 5.77^{*}$ \\
\hline & P3 & $22.75 \pm 16.99$ & $31.00 \pm 5.77$ \\
\hline
\end{tabular}

Tanda * pada tabel menunjukan perbedaan yang nyata

Rata-rata latensi percumbuan mencit jantan kelompok muda yang diberi ekstrak lada hitam tidak berbeda nyata dibandingkan dengan kontrol, namun terdapat perbedaan nyata pengaruh P1 dan P2 mencit jantan kelompok tua dengan kontrol. Hal ini menunjukkan ada pengaruh perlakuan terhadap mencit janan tua, yaitu dengan cara meningkatkan daya penciuman mencit jantan tua, sehingga mempersingkat latensi percumbuan.

Zat aktif lada hitam yang berfungsi sebagai antioksidan dapat meningkatkan kebugaran, sehingga daya penciuman mencit jantan terhadap feromon yang dikeluarkan oleh mencit betina dapat dideteksi dengan baik oleh Vomeronasal Organ. Sinyal feromon ini kemudian diteruskan menuju amigdala dan MPOA (Medial Preoptic Area). Zat aktif piperin lada hitam dapat me- ningkatkan kadar hormon gonadotropin dalam serum dengan cara menghambat feedback negatif ke hipofisis pada tikus jantan (D'Cruz dan Mathur, 2005). Gonadotropin yang dihasilkan hipofisis, terutama LH akan merangsang testis, dalam hal ini sel Leydig, untuk menghasilkan testosteron (Molina, 2004). Testosterone sendiri merupakan hormon penting yang bekerja pada amigdala dan MPOA. Testosteron berperan mengatur perilaku seksual terutama meningkatkan pemrosesan input sensori terhadap stimulus feromon, sehingga sangat berperan dalam aktivitas percumbuan (Hull et al., 2004).

Pada mencit jantan kelompok muda, tidak ada pengaruh ekstrak lada hitam terhadap latensi percumbuan dibandingkan dengan kontrol. Dosis ekstrak lada hitam dapat menjadi faktor yang mempengaruhi hal tersebut, sehingga pada kelompok muda, maupun tua diperlukan pemberian dosis ekstrak lada hitam yang berbeda-beda agar dapat diketahui dosis ekstrak lada hitam yang tepat untuk mempersingkat latensi percumbuan bagi masing-masing kelompok umur mencit jantan.

\section{Latensi Penunggangan}

Tabel 3. Rata-rata latensi penunggangan mencit jantan (detik) antara kelompok umur muda dan tua

\begin{tabular}{ccc}
\hline \multirow{2}{*}{ Perlakuan } & \multicolumn{2}{c}{ Latensi Penunggangan \pm SD (detik) } \\
\cline { 2 - 3 } K2 & K1 & $479.25 \pm 218.79$ \\
\hline P0 & $489.25 \pm 151.51$ & $314.00 \pm 234.35$ \\
\hline P1 & $249.75 \pm 264.65$ & $496.00 \pm 123.50^{*}$ \\
\hline P2 & $126.00 \pm 91.63^{*}$ & $359.00 \pm 286.03$ \\
\hline P3 & $390.50 \pm 276.49$ &
\end{tabular}

Tanda * pada tabel menunjukan perbedaan yang nyata

Hasil analisis statistik menunjukan bahwa ratarata latensi penunggangan mencit jantan P0, P1, P3 kelompok muda dengan kelompok tua tidak berbeda nyata, namun terdapat perbedaan nyata pada P2 kelompok muda dengan kelompok tua.

Tabel 4. Rata-rata latensi penunggangan mencit jantan (detik) antara perlakuan kontrol dengan perlakuan ekstrak lada hitam

\begin{tabular}{cccc}
\hline \multirow{2}{*}{ Umur Perlakuan } & \multicolumn{3}{c}{ Latensi Penunggangan \pm SD (detik) } \\
\cline { 2 - 4 } & & $\begin{array}{c}\text { Diberi ekstrak } \\
\text { lada hitam }\end{array}$ & Kontrol (P0) \\
\hline \multirow{3}{*}{$\mathrm{K} 1$} & $\mathrm{P} 1$ & $249.75 \pm 264.65$ & $489.25 \pm 151.51$ \\
\cline { 2 - 4 } & $\mathrm{P} 2$ & $126.00 \pm 91.63^{*}$ & $489.25 \pm 151.51^{*}$ \\
\cline { 2 - 4 } & $\mathrm{P} 3$ & $390.50 \pm 276.49$ & $489.25 \pm 151.51$ \\
\hline \multirow{2}{*}{$\mathrm{K} 2$} & $\mathrm{P} 1$ & $314.00 \pm 234.35$ & $479.25 \pm 218.79$ \\
\cline { 2 - 4 } & $\mathrm{P} 2$ & $496.00 \pm 123.50$ & $479.25 \pm 218.79$ \\
\cline { 2 - 3 } & $\mathrm{P} 3$ & $359.00 \pm 286.03$ & $479.25 \pm 218.79$ \\
\hline Tanda * pada tabel menunjukan perbedaan yang nyata
\end{tabular}

Rata-rata latensi penunggangan mencit jantan kelompok P2 berbeda nyata dibandingkan de- 
ngan kontrol. Hal ini menunjukan bahwa ada pengaruh perlakuan dan umur terhadap latensi penunggangan. Ekstrak etanol mampu secara nyata mempersingkat latensi penunggangan mencit jantan kelompok muda dibandingkan kelompok tua serta mempersingkat latensi penunggangan mencit jantan kelompok muda dibandingkan kontrol.

Ekstrak etanol buah lada hitam lebih banyak mengandung piperin karena etanol adalah larutan yang baik melarutkan piperin dibandingkan air (Kohle et al., 2011). Melalui penelitian terdahulu diketahui bahwa piperin dapat mempengaruhi sistem hormon reproduksi dengan cara meningkatkan kadar hormon gonadotropin dalam serum dengan cara menghambat feedback negatif ke hipofisis pada tikus jantan (D'Cruz dan Mathur, 2005). Gonadotropin yang dihasilkan hipofisis, terutama LH akan merangsang testis, dalam hal ini sel Leydig, untuk menghasilkan testosteron (Molina, 2004). Testosteron akan meningkatkan NOS (Nitric Oxide Synthase) dalam MPOA, sehingga terjadi peningkatan kadar NO yang akan mengakibatkan peningkatan pelepasan dopamin di beberapa area integratif, sehingga timbul libido yang mendukung output motorik berupa penunggangan (Hull et al., 2004). Namun pada dosis piperin yang tinggi, piperin dapat menyebabkan penurunan aktivitas enzim antioksidan dan level asam sialat pada epididimis, sehingga terjadi peningkatan kadar oksigen reaktif yang dapat merusak lingkungan epididimis dan fungsi sperma (D'Cruz dan Mathur, 2005).

\section{Frekuensi Penunggangan}

Tabel 5. Rata-rata frekuensi penunggangan mencit jantan antara kelompok umur muda dan tua

\begin{tabular}{ccc}
\hline \multirow{2}{*}{ Perlakuan } & \multicolumn{2}{c}{ Frekuensi Penunggangan \pm SD } \\
\cline { 2 - 3 } & $\mathrm{K} 1$ & $\mathrm{~K} 2$ \\
\hline P0 & $1.00 \pm 1.41$ & $0.50 \pm 0.58$ \\
\hline P1 & $4.00 \pm 2.83$ & $2.00 \pm 2.16$ \\
\hline P2 & $5.25 \pm 2.22^{*}$ & $1.50 \pm 1.73^{*}$ \\
\hline P3 & $1.50 \pm 1.91$ & $2.25 \pm 3.30$ \\
\hline
\end{tabular}

Tanda * pada tabel menunjukan perbedaan yang nyata

Hasil uji satatistik menunjukan bahwa rata-rata frekuensi penunggangan mencit jantan P0, P1, P3 kelompok muda dengan kelompok tua tidak berbeda nyata. Rata-rata frekuensi penunggangan mencit jantan P2 kelompok muda dengan kelompok tua berbeda nyata.

Rata-rata frekuensi penunggangan mencit jantan kelompok P2 berbeda nyata dibandingkan dengan kontrol. Hal ini menunjukan bahwa ada pengaruh perlakuan dan umur terhadap frekuensi penunggangan. Ekstrak etanol buah lada hitam mampu secara nyata meningkatkan frekuensi penunggangan mencit jantan kelompok muda dibandingkan kelompok tua serta mempersingkat frekuensi penunggangan mencit jantan kelompok muda dibandingkan kontrol.

Tabel 6. Rata-rata frekuensi penunggangan mencit jantan antara perlakuan kontrol dengan perlakuan ekstrak lada hitam

\begin{tabular}{cccc}
\hline \multirow{2}{*}{ Umur Perlakuan } & \multicolumn{2}{c}{ Frekuensi Penunggangan \pm SD } \\
\cline { 2 - 4 } & & $\begin{array}{c}\text { Diberi ekstrak } \\
\text { lada hitam }\end{array}$ & Kontrol (P0) \\
\hline \multirow{2}{*}{ K1 } & P1 & $4.00 \pm 2.83$ & $1.00 \pm 1.41$ \\
\cline { 2 - 4 } & P2 & $5.25 \pm 2.22 *$ & $1.00 \pm 1.41^{*}$ \\
\cline { 2 - 4 } K2 & P1 & $1.50 \pm 1.91$ & $1.00 \pm 1.41$ \\
\cline { 2 - 4 } & P2 & $1.50 \pm 1.73$ & $0.50 \pm 0.58$ \\
\cline { 2 - 4 } & P3 & $2.25 \pm 3.30$ & $0.50 \pm 0.58$ \\
\hline Tanda * pada tabel menunjukan perbedaan yang nyata
\end{tabular}

Telah di jelaskan sebelumnya bahwa ekstrak etanol buah lada hitam lebih banyak mengandung piperin (Kohle et al., 2011). Piperin tidak hanya memberi efek mempersingkat latensi penunggangan, tetapi juga meningkatkan frekuensi penunggangan pada mencit jantan muda. Hal tersebut dikarenakan piperin dapat meningkatkan sekresi testosteron sehingga terjadi peningkatan intensitas dorongan seksual mencit jantan. Selain mengatur intensitas dorongan seksual jantan, testosterone memiliki berbagai pengaruh lain yang hanya berhubungan secara tidak langsung dengan aktivitas reproduksi. Dengan adanya korelasi antara libido dengan testosteron, maka sangat diharapkan bahwa kadar testosteron yang tinggi dapat memperbaiki dorongan seks yang rendah ataupun impotensi pada jantan (Nalbandov, 1990).

\section{SIMPULAN}

Dari hasil penelitian dan pembahasan dapat disimpulkan bahwa:

1. Ekstrak lada hitam mampu meningkatkan libido dengan cara mempersingkat latensi percumbuan pada mencit jantan tua dan mampu mempersingkat latensi penunggangan serta meningkatkan frekuensi penunggangan pada mencit jantan muda.

2. Perbedaan umur pada mencit jantan yang diberi ekstrak lada menunjukan ada perbedaan latensi dan frekuensi penunggangan.

3. Pemberian ekstrak etanol lada hitam lebih baik dalam meningkatkan libido mencit jantan.

\section{DAFTAR PUSTAKA}

D'cruz S.C. dan P.P. Mathur. 2005. Effect of Piperine on the Epididymis of Adult Male 
Rats. Asian Journal of Andrology. 7(4): 363-8.

Darling, L. M. 2002. Spices As Aphrodisiacs. unitproj.library.ucla.edu/biomed/spice/inde x.cfm?spicefilename=aphrodisiacs.txt\&ite msuppress=yes\&displayswitch $=0 .(30 \mathrm{Ma}-$ ret 2013).

Hull, E.M., J.W. Muschamp, dan S. Sato. 2004. Dopamine and Serotonin: Influences on Male Sexual Behavior. Physiology \& Behavior. 83: 291-307.

Kolhe, S.R., P. Borole, dan U. Patel. 2011. Extraction and Evaluation of Piperine from Piper nigrum Linn. International Journal of Applied Biology and Pharmaceutical Technology. 2 (2): 144-9.
Majeed, M dan L. Prakash. 2000. The Medicinal Uses of Pepper. International Pepper News. 25 (1): 23-31.

Meghwal, M. dan T. K. Goswami. 2012. Nutritional Constituent of Black Pepper as Medicinal Molecules: A Review. Open Access Scientific Reports. 1: 1-7.

Molina, E. P. 2004. Endocrine Physiology. McGraw-Hill Professional. New York.

Nalbandov, A.V. 1990. Fisiologi Reproduksi pada Mamalia dan Unggas. Universitas Indonesia Press. Jakarta.

Syamsul, E. S. 2011. Tumbuhan Obat Berkhasiat Afrodisiaka Penambah Vitalitas Pria. Jogja Mediautama. Yogyakarta. 